\title{
ドリル形状に基づく特性予測システムの開発
}

河合 貴未央 ${ }^{* 1}$, Beaucamp Anthony $^{* 2}$, 今泉 紀幸*3, 櫻井 正俊*3, 竹内 芳美*4

\section{Development of drill property prediction system based on drill shape}

\author{
Kimio KAWAI ${ }^{* 1}$, Anthony BEAUCAMP ${ }^{* 2}$, Noriyuki IMAIZUMI ${ }^{* 3}$, Masatoshi SAKURAI ${ }^{* 3}$ \\ and Yoshimi TAKEUCHI ${ }^{*}$
}

\author{
${ }^{* 1,{ }^{* 4}}$ Department of Mechanical Engineering, Chubu University \\ 1200 Matsumoto-cho, Kasugai-shi, Aichi 487-8501, Japan \\ ${ }^{* 2}$ Department of Micro-Engineering, Kyoto University \\ Cluster C3, Kyoto University Katsura, Nishikyo-ku, Kyoto 615-8540, Japan \\ ${ }^{*}$ OSG CORPORATION \\ 2-17 Shirakumo-cho, Toyokawa-shi, Aichi 442-0018, Japan
}

Received: 9 April 2017; Revised: 31 July 2017; Accepted: 9 October 2017

\begin{abstract}
In recent years, the drill used to make holes is expected to exert both high machining accuracy and good processing capability. In order to meet those requirements, it is necessary to develop a new drill shape with good properties requested by designers. There is a strong need for a new system to shorten the drill fabrication time, to reduce material costs, and to create new drill configurations by predicting their characteristics. Current drill shape prediction systems cannot comprehensively and mathematically treat drill cross-section shape including the cutting edge, groove and so on. The prediction system would become more practical if the drill specification was mathematically formulated. This study reports the development of a system to predict not only the cross-sectional shape but also various parameters from the information of grinding wheels used in drill fabrication. Furthermore, this study proposes the new system to predict the most suitable grinding wheel setting from the grinding wheel shape and some drill specifications as the reverse process.
\end{abstract}

Keywords : Drill fabrication, Drill cross-section, Drill specification, Simulation software, Grinding wheel position

\section{1. 緒言}

近年，5 軸制御加工機をはじめとする NC 工作機械の発達により今まで製作が困難であった複雑な形状を高精 度かつ高効率に加工をすることが可能になっている（濱田他，2011）（小畑他，2004）（小谷他，2009）（窪田他， 2010)。また，加工に用いる被削材においてもCFRPなどの新素材に対応しなければいけないが，従来の工具では 摩耗の進行速度が著しいという問題も生じ，加工の状況も日々変化している（大橋他，2013）(岡田他，2012）.

このような状況下で，穴あけに必須なドリルには，より高精度な加工ができるドリルや，難削材においてでも 安定した加工ができるドリルが新製品として求められている(柴田他，1992）。ドリルの使用にあたっては，切り 屑排出のシミュレーションなどは可能になっているものの（松村，2014），ドリル開発では，製品化するまでに 試し研削と呼ばれるドリル製造のための研削加工が複数回行われている．この試し研削では，目的のドリル形状 を創成するために必要な砥石形状や研削条件を見つけるために，これらの加工条件を何回も変え，実際に研削加 工を行って得られた形状をチェックしながら実施されている．実際に研削加工を行うために時間がかかり，加工 の回数が増えるほど材料費もかかる．そこで，砥石形状と研削条件を入力するだけで創成されるドリル断面形状

No.17-00162 [DOI:10.1299/transjsme.17-00162], J-STAGE Advance Publication date : 18 October, 2017

${ }^{* 1}$ 正員, 中部大学大学院工学研究科（广487-8501 愛知県春日井市松本町 1200)

*2 京都大学工学研究科マイクロエンジニアリング専攻（率615-8540 京都府京都市西京区京都大学桂 C3 棟)

*3 オーエスジー (株) (广442-0018 愛知県豊川市白雲町 2-17)

*4 正員, フェロー, 中部大学工学部

E-mail of corresponding author: takeuchi_yoshimi@isc.chubu.ac.jp 
とそれよりドリル諸元を予測できるシミュレーションソフトウェアがあれば実際に加工を行うことなく形状確認 ができる．このようなソフトウェアを利用できれば複数回必要な加工を削減することができるので生産性の向上 と材料費の削減につながる，本研究では，OSG 社製のシミュレーションソフトウェアを利用してこのシステム を開発する。

OSG 社製のシミュレーションソフトウェアの現状は，砥石形状と研削条件から研削軌跡をシミュレーション することが可能となってはいるものの，この研削軌跡からドリル外形を抽出し，ドリル断面形状を予測すること ができていない．また，このソフトウェアではすくい角やランド角などといったドリル諸元を算出できることを 目標としているが，ドリル外形の抽出ができていないため，諸元の算出ができていない．
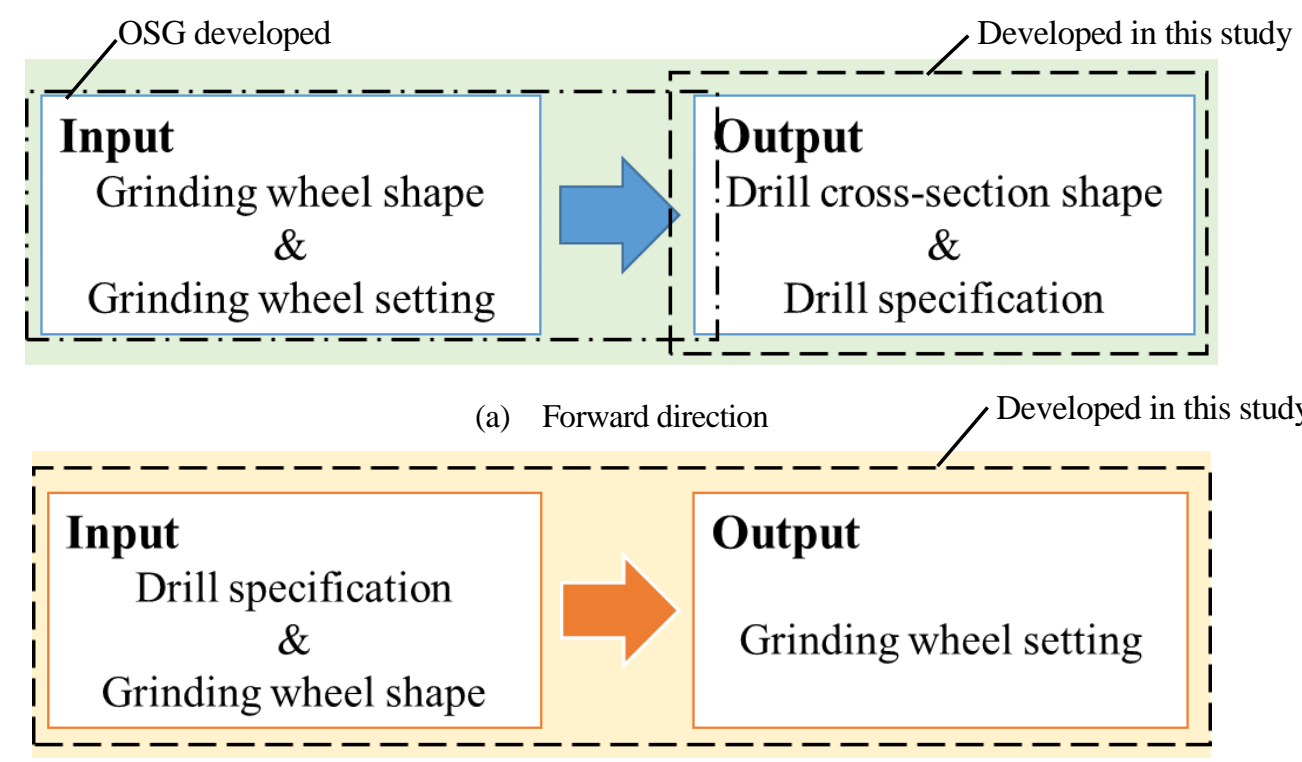

(b) Reverse direction

Fig.1 Prediction system in this study

そこで, 本研究では, 図 1 に示すようにシミュレーションソフトウェアによって生成された研削軌跡からド リル外形を抽出し，ドリル断面形状を予測し，抽出したドリル外形からドリル諸元を算出する手法を提案する.

しかし，これらは外国製の既存ソフトウェアで可能になっている，一方，必要な性能を有するドリル製作には ドリル諸元を決め，加工に必要な砥石を選ぶが，砥石をじのように設定するかは経験を基に試行錯誤することで 行われている，そこで，砥石形状とドリル諸元から砥石振り角と砥石オフセットといった砥石設定を予測するシ ステムの開発を行った．砥石形状と砥石設定からドリル断面形状予測と諸元算出をするシステムを順方向プロセ ス（図1（a)）とすると，これは逆方向のシステム（図 1（b)）なる.このシステムによって, 砥石設定が未知 の場合に最適な砥石設定を自動的に決定することが可能となり，高効率なドリル製造が期待できる.

\section{2. 順方向プロセスの開発}

\section{$2 \cdot 1$ ドリル形状創成とドリル諸元の予測}

\section{$2 \cdot 1 \cdot 1$ 研削碈石によるドリル形状創成}

初めに，ドリル形状創成について説明する．ドリルを製作する上では，まず目的の溝形状を削り出すために 最適な研削砥石形状を選定する．次に研削条件を設定して加工を行うが，ここで最も重要な条件が砥石設定であ る.この砥石設定とは, 図 2 のように，ドリル素材の軸方向に対して砥石を傾けた角度である砥石振り角と，ド リル素材と砥石の接触面にクリアランスを設定する砥石オフセットを指す。この砥石設定によって創成される溝 形状は大きく変化する. 


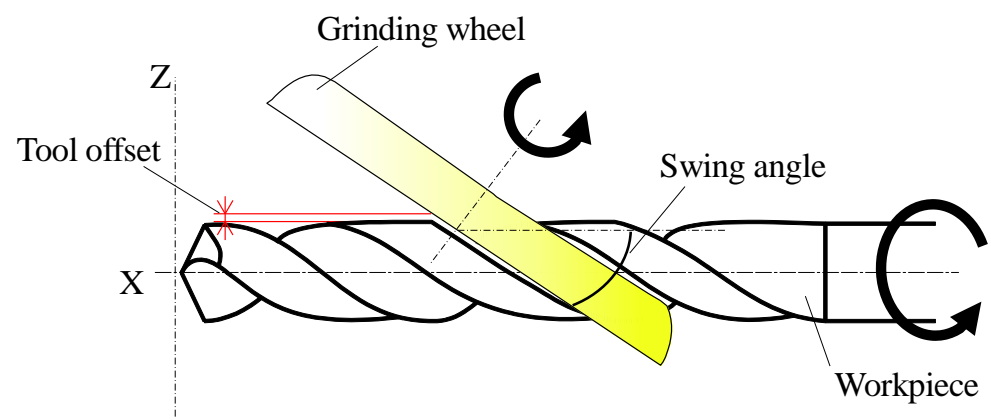

Fig.2 Setting of grinding wheel

この研削砥石形状と砥石設定を基に，図 3 のように砥石が材料に切り込んでいくことによってドリル溝は創 成されていく，このとき，螺旋溝を作るために材料も回転している.

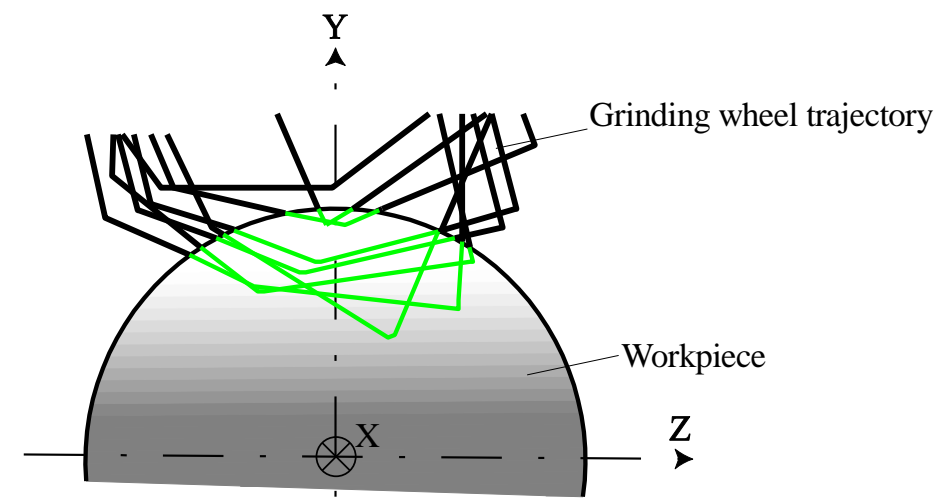

Fig.3 Generation of drill groove

\section{$2 \cdot 1 \cdot 2$ シミュレーションソフトウェアによるドリル断面形状予測}

本研究で利用するシミュレーションソフトウェアでは, 加工に用いる研削砥石形状と, 砥石振り角や切込み 量などの研削条件を入力することによってドリル断面形状（㛜密には断面形状ではなく砥石断面重畳軌跡）を予 測することができる．このとき，研削砥石形状として図４に示すように砥石研削面の外形（断面）を線分分解し て点群で近似的に表現している．この砥石形状が図 3 に示すような運動をするときの点群の軌跡がドリル断面形 状を構成する.

図 5 （a）は実際にあるドリルを軸方向から撮影したもので，図 5 (b) は同形状のドリルと本研究で利用する ソフトでシミュレーションソフトウェアを適用した結果である. 図 5 （b）において，緑・赤・黄色で表されて いる領域はそれぞれドリルを構成する溝工程や背抜き工程などの工程で研削砥石によって削り取られる部分であ る. 実際のドリル形状はこの領域以外の部分となる。また，このシミュレーションソフトウェアでは一部の断面 形状のみが確認できるのではなく，ドリルの溝長のどの部分においてでも断面形状を確認することができる.

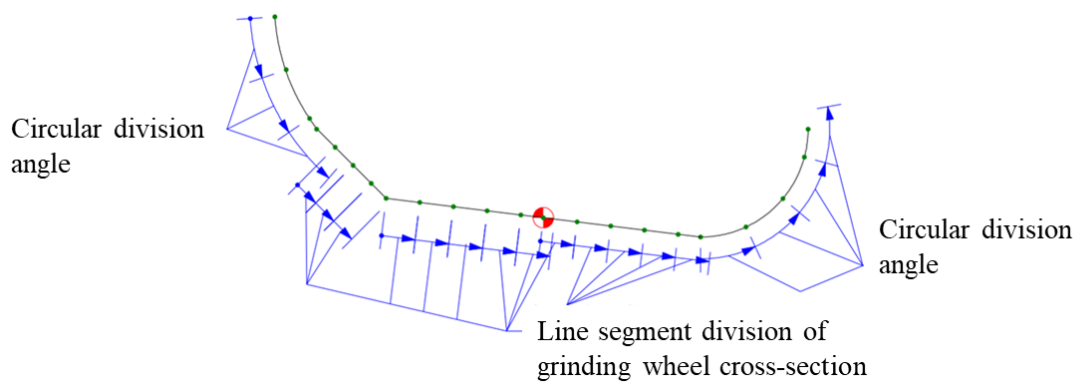

Fig.4 Line segment division of grinding wheel cross-section 


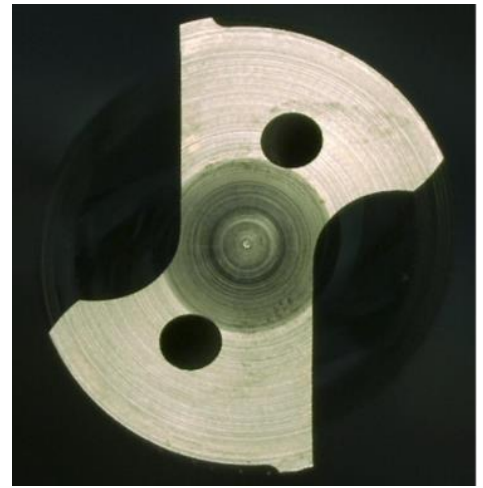

(a) Front view of the actual drill

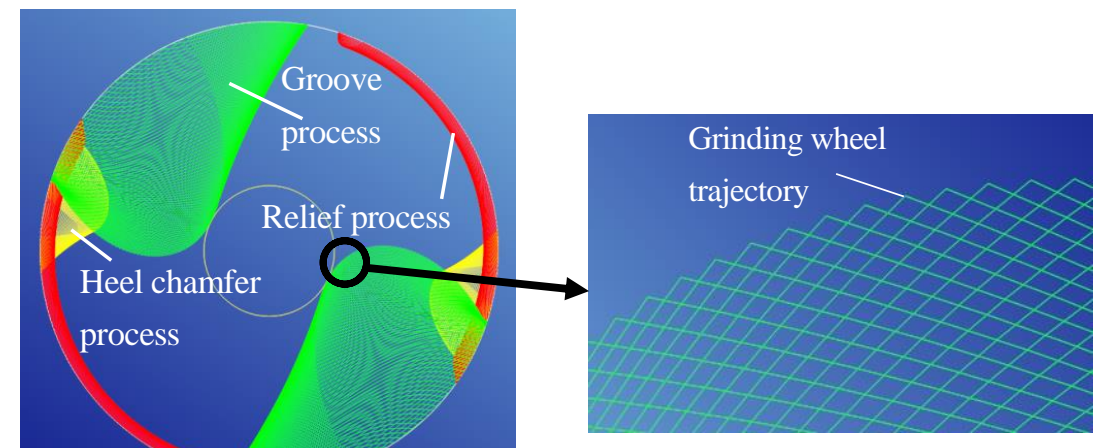

(b) Front view of simulated cross-section (c) The expanded grinding wheel trajectory calculated by the simulation software

Fig.5 Actual and computed drill cross-section by a simulation software

\section{$2 \cdot 2$ ドリル断面形状の予測}

\section{$2 \cdot 2 \cdot 1$ ドリル外形点の抽出}

シミュレーションソフトウェアで得られる研削軌跡はドリル外形を表しているわけではなく，図 5 (c) のよう に点群で表された砥石形状が多数オーバーラップしているだけである.

そこでこの研削軌跡の点データの中からドリル外形点のみを抽出することを考える．提案する手法は図 6 のよ うな流れで構成されている。ここで，ドリル形状は，大きく分けると溝外形に凹み部分をもたない形状と，凹み 部分をもつ形状の 2 タイプからなることに留意しなければならない.

まず, 砥石研削軌跡の点データに対して凸包の計算を行い, 軌跡の外周部の点データだけを抽出する.しかし， 凸包によって抽出された点データには，材料円周部の点データが含まれており，この点データはドリル外形点を 抽出する上で不要な点になる. そこで, ある点を中心に隣り合う点を結んで得られるべクトルの内積の計算をし， この值の変化をもとに材料円周部とドリル溝外形点の交点にあたる境界点を求める. ある点を中心とした内積は 1 なら直線状に，0 なら 90 度の変化になるので，2つの境界点以外では 1 に近く，境界点では 0.5 以下になるこ とを利用して自動判別可能である，材料円周部の点は，ドリル中心からの距離がドリルの半径に近い值になるこ とを用いて削除している。

このような方法によって，凹み部分をもたない形状（図７（a）が典型的）ではドリル外形点の抽出を実現で きる.一方，凹み部分をもつ形状（図 8 (a) が典型的）においては，外形点データに欠損部ができるために適 正化を行う必要がある。そこで，ドリル形状がどちらのタイプかを判定するために，各点間の距離で外れ值の有 無を探索する．凹み部分をもつ形状では，各点間の距離に対して，凹み部分がない形状には存在しないような大 きく距離が離れる点が存在する。これを利用して各点間の距離から外れ值を検出できれば形状のタイプの判定が できることになる．外れ值の検出のために，点間の距離でロバスト統計を利用した正規分布の計算を行い，信頼 区間 95\%の值を超えるデータが存在する場合に凹み部分をもつ形状であると判定する（曲他，2013）.

外れ值を検出し，凹み部分を有すると判定された形状では，凸包の計算では正確な溝外形を抽出できない. そ のため, MATLAB 関数 boundary を利用して外形点の抽出を行う. 関数 boundary を適用すると，点の集合の境界 を点群の内側に縮小することができるため，例えば図 9 に示すように凹み部分をもつ形状においても溝外形点抽 出を実現することができる，これによって，凹み部分が存在してもドリル外形点データを与えることができ，正 確な外形点を抽出できる. 


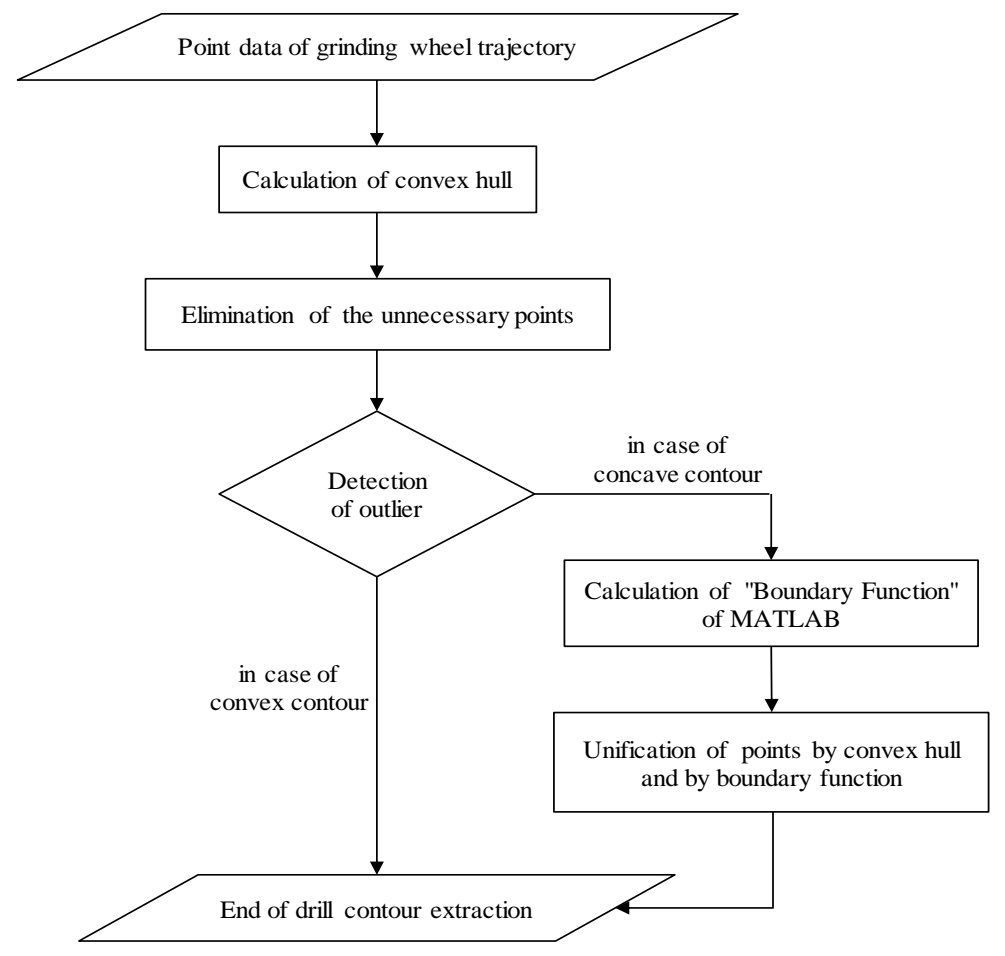

Fig.6 Flow of drill contour extraction

以上の計算手法を利用し，ある2 タイプのドリル形状においてドリル外形点の抽出をした結果を図 7 と図 8 に 示す．図 7 (a) と図 8 (a) が研削砥石軌跡の点データであり, 次の図 7 (b) と図 8 (b) が凸包の計算結果であ る.そして，図７（c）と図８（c）がそれぞれのタイプのドリルの外形点である.

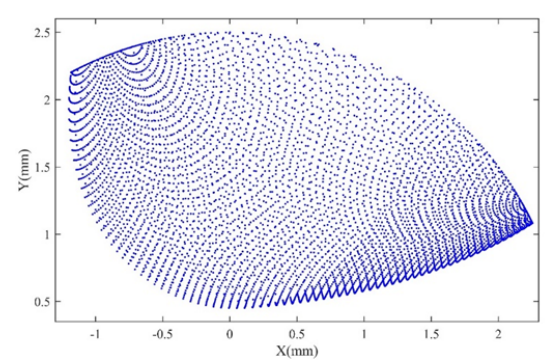

(a) Grinding wheel trajectory points

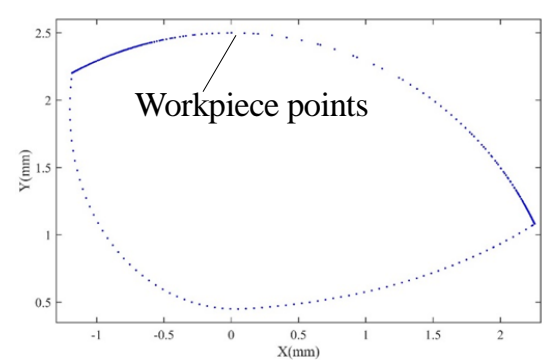

(b) Recognition of the convex hull

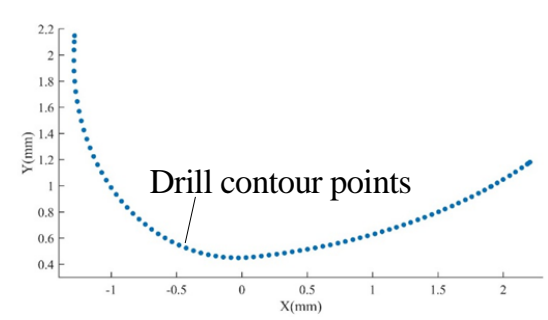

(c) Extracted drill contour points

Fig.7 Extraction of convex drill contour points

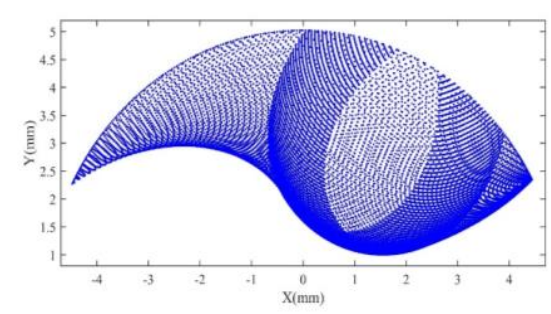

(a) Grinding wheel trajectory points

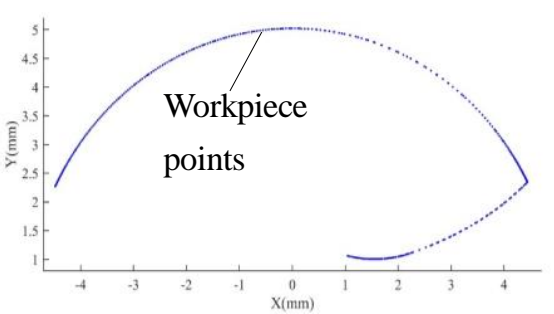

(b) Recognition of the convex hull

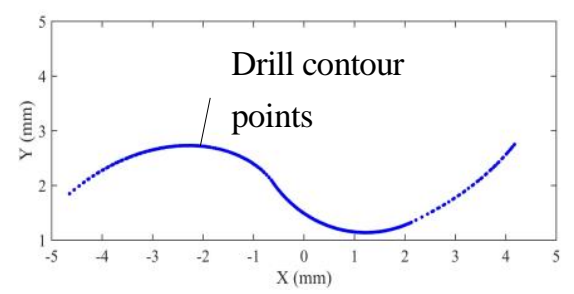

(c) Extracted drill contour points

Fig.8 Extraction of concave drill contour points 


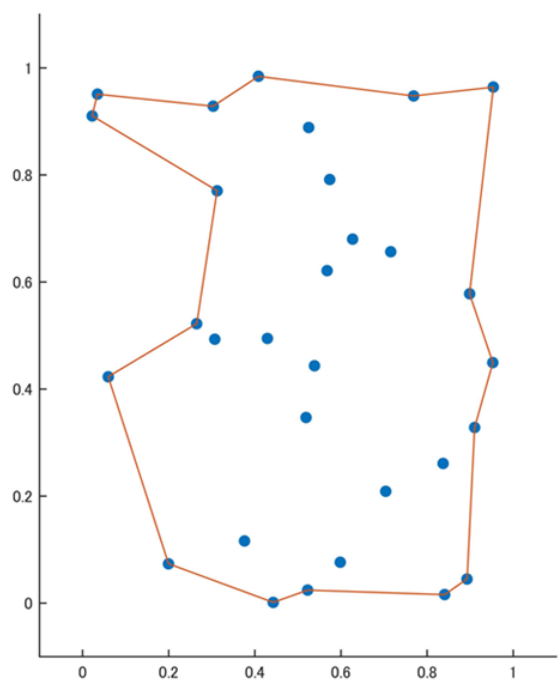

Fig.9 Calculation result of MATLAB boundary function

\section{$2 \cdot 2 \cdot 2$ 断面形状の予測結果}

2.2.1 節で提案した手法を利用し，ドリル製作のための溝・背抜き・ヒール面取りなどの各工程において，研削 砥石の軌跡の点データからこれらの各工程を処理したドリルの溝外形点の抽出結果を図 10 に示す．図 10 (a) は 対象形状で研削軌跡のシミュレーションをした結果で，図 10 （b） は各工程の研削軌跡から外形点を抽出したも のである.

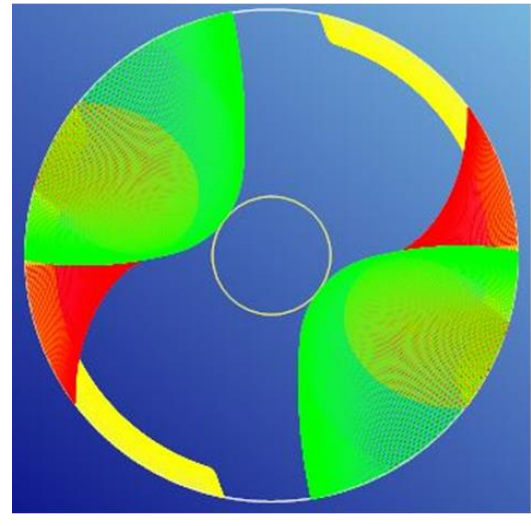

(a) Simulated grinding wheel trajectory

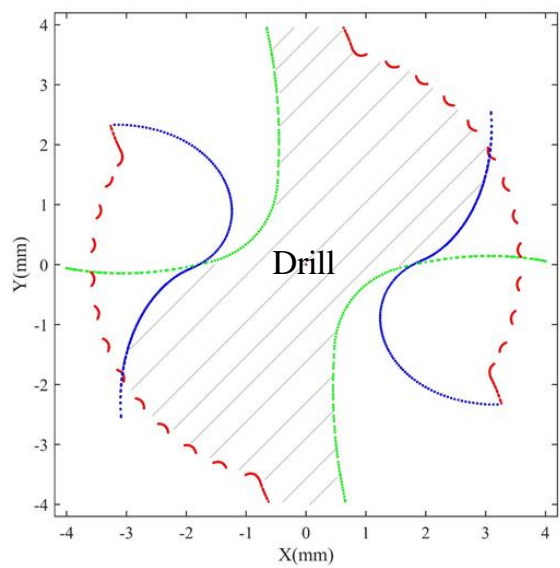

(b) Extracted drill cross-section

Fig.10 Drill cross-section extracted from simulated grinding wheel trajectory

\section{$2 \cdot 3$ ドリル諸元の算出}

\section{$2 \cdot 3 \cdot 1$ ドリル外形点の関数化}

2.2 節によって抽出したドリル外形点を利用し，ドリル諸元の算出をする。－－部の諸元を算出するためには抽 出したドリル外形点を関数近似する必要がある。そこで，最小二乗法を利用し，低い次数で精度の良い近似を実 現する.このとき，諸元算出時に外形点を全て近似すると精度が悪くなることがあるので，諸元算出に必要な外 形点をいくつか抜き出し，この抜き出した点データを最小二乗法によって近似することで精度の良い近似を行 う.

諸元算出の例として諸元で最も重要なすくい角を取り上げる. すくい角を算出するためには，すくい角測定長 さ（Base distance）を入力值として与えることが必要である. 次に，すくい角測定長さを半径として中心を刃先 
点とする円を定義し，この円とドリル外形の交点を算出する. 算出した交点 $P_{i}$ と刃先点 $P_{e}, \quad$ ドリル中心点 $P_{c}$ の 3 点のな寸角がすくい角となる. 図 11 はすくい角の定義を図示したものである. ここで，点 $P_{\mathrm{i}}$ を算出するため に，まず外形点のどの区間にすくい角測定長さを半径とする円の交点があるかを調べる．次に，この交点の両隣 の溝外形点とさらに両隣の合計 4 点を使って, 最小二乗法によって溝外形状を 2 次関数で表し，これと円との交 点を求めている. その他の諸元においても同様に関数化を行って算出している.

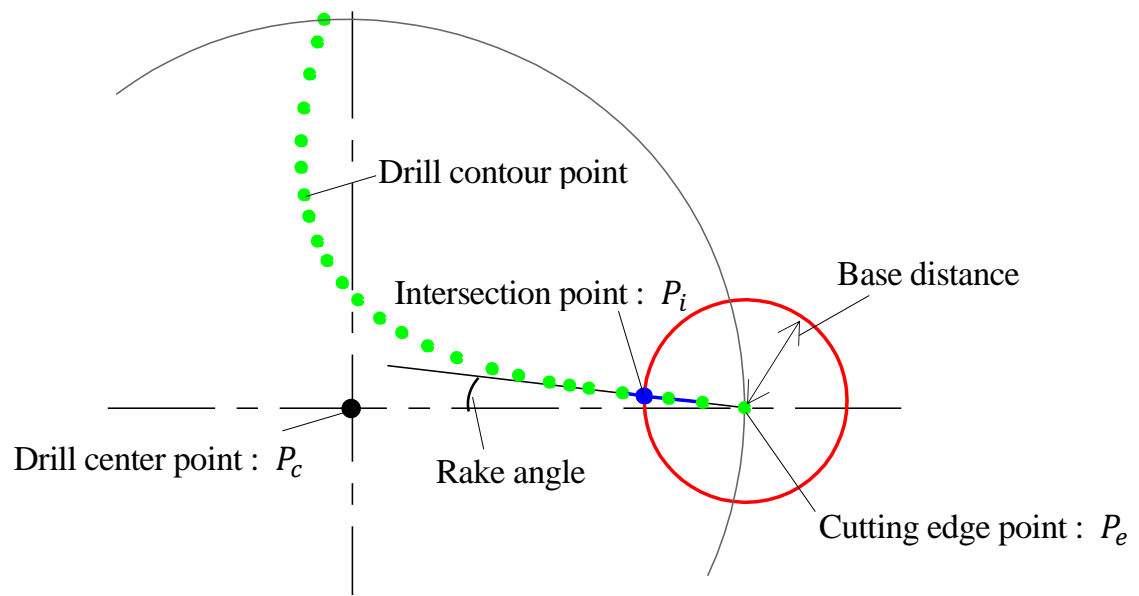

Fig.11 Definition of rake angle

\section{$2 \cdot 3 \cdot 2$ ドリル諸元の算出結果}

2.3.1 節で提案した近似法を利用して外形点を近似する必要のあるドリルの諸元值を算出した結果を表 1 に示 す．表のように参考值と同様な諸元值を算出することができている．ここで，すくい角測定長さと直線刃部径は 入力值であり，参考值は外国製シミュレーションソフトウェアによる計算值である．参考值はドリルメーカーに おいて実際に使用されているが，本研究によって得られた計算值はドリルメーカーにおいて特に問題ない範囲の 值になっており，この計算結果は有用であることを確認している.

Table 1 Drill specification obtained by the proposed method

\begin{tabular}{|c|c|c|c|}
\hline \multirow{2}{*}{ Input value } & \multicolumn{2}{|c|}{ Base distance(rake angle) (mm) } & 0.25 \\
\hline & \multicolumn{2}{|c|}{ Diameter of straightness (mm) } & 4.2 \\
\hline Various elements of Drill & Reference & \multicolumn{2}{|c|}{ Calculated } \\
\hline Rake angle (deg) & 13.74 & \multicolumn{2}{|c|}{13.683} \\
\hline Web thickness (mm) & 2.046 & \multicolumn{2}{|c|}{2.085} \\
\hline Length of straightness (mm) & 3.06 & \multicolumn{2}{|c|}{3.091} \\
\hline Distance betw.back edges (mm) & 6.572 & \multicolumn{2}{|c|}{6.497} \\
\hline Circular land (deg) & 55.113 & \multicolumn{2}{|c|}{54.738} \\
\hline Intersec.point diam (mm) & 9.614 & \multicolumn{2}{|c|}{9.6095} \\
\hline Intersection point angle (deg) & 121.069 & \multicolumn{2}{|c|}{122.1369} \\
\hline
\end{tabular}




\section{3. 逆方向プロセスの開発}

\section{$3 \cdot 1$ 砥石設定法}

前章までは定義した研削砥石形状と研削条件から創成されるドリル断面形状を抽出し，さらにドリル諸元を 予測するという順方向のシステム開発を行ったが，本章では逆方向のシステムを扱う。すなわち，砥石形状とド リル諸元を指定するとその諸元をもつドリルを加工する砥石設定を予測するものである．研削条件の中で砥石設 定は，創成されるドリルの形状に大きく影響することと，諸元を満足できる砥石設定を見つけることは手間がか かるため，適切な砥石設定を自動的に予測することは段取り時間の短縮につながる.

砥石設定の予測はドリル諸元の一部を目標にして行う。ドリル切れ刃形状には 2 つタイプが存在し，一方の フックタイプのドリルでは，すくい角とランド角，もう一方のストレートタイプのドリルでは，すくい角，ラン ド角， $\mathrm{R}$ 入り組み量のドリル諸元によって予測をする。ここで，砥石設定の際の砥石振り角と砥石オフセットの 2 つ条件の変化がドリル諸元に及ぼす影響を調べると，砥石振り角の大小はドリル諸元に大きく影響するだけ でなく，各ドリル諸元には規則性があることが分かった。あるドリル形状において検証した結果を図 12 に示 す.

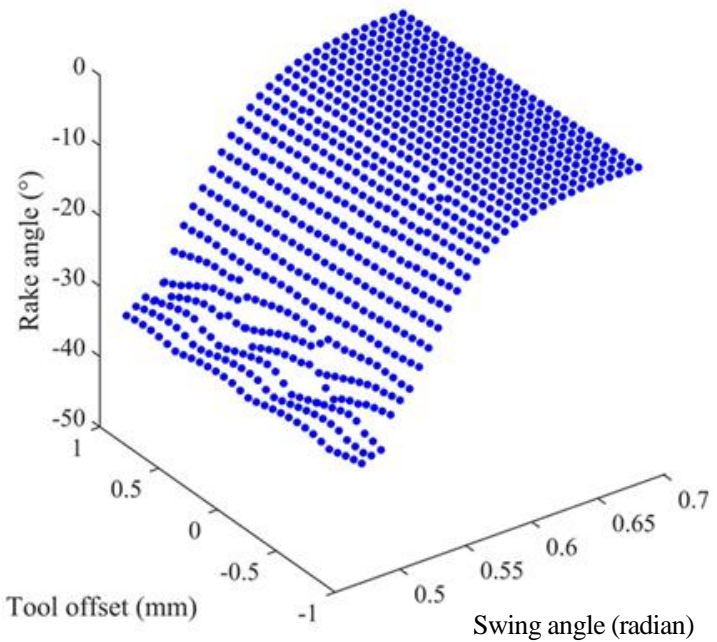

(a) to rake angle

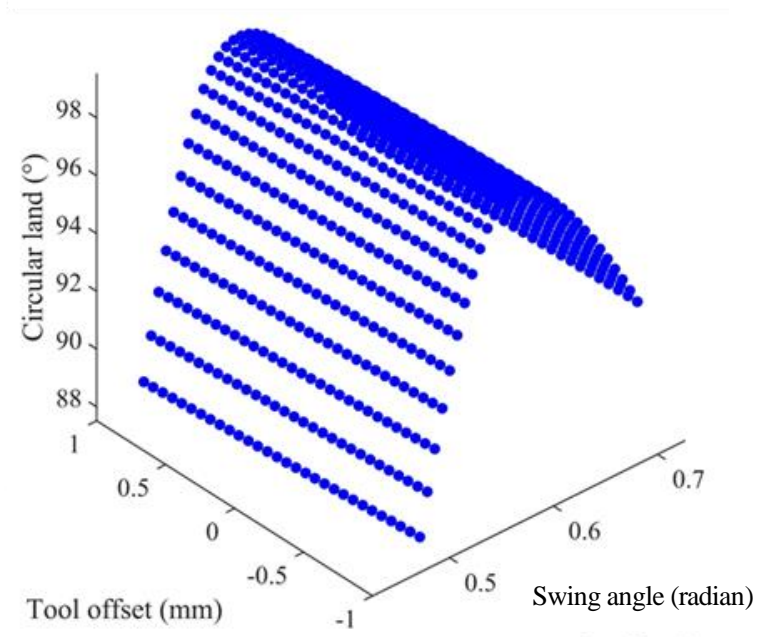

(b) to circular land

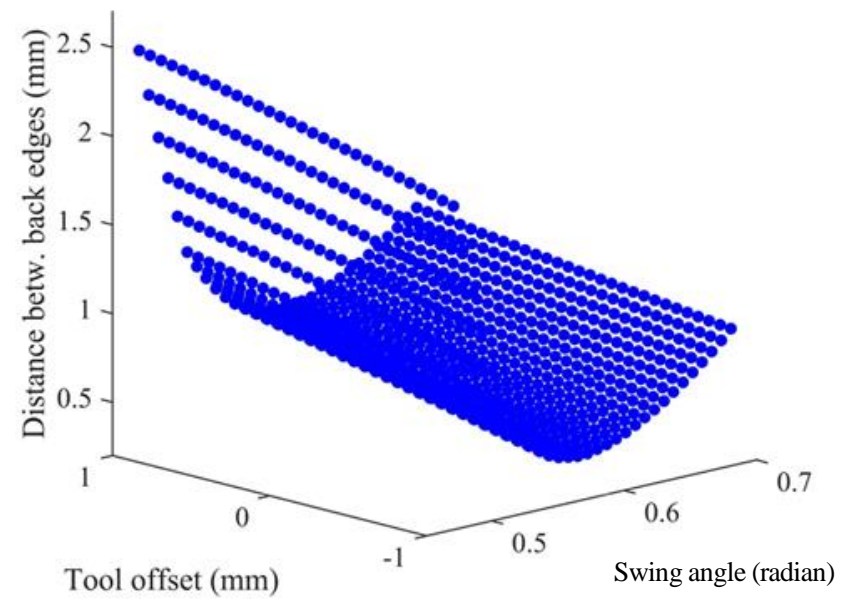

(c) to distance between back edges

Fig.12 Influence of tool offset and swing angle to drill specifications 
そこで，入力した砥石設定の推定值に対して最適值の探索範囲とその刻みを定義し，このときの砥石設定の各 条件におけるドリル諸元值を算出する．各ドリル諸元值には公差が定義されているので，算出したドリル諸元值 が公差内にあれば，その砥石設定条件とそのときのドリル諸元值を記憶する．このドリル諸元值を与える砥石振 り角を $\mathrm{x} に ，$ 砥石オフセットを $\mathrm{y} に ，$ 各ドリル諸元值を $\mathrm{z}$ とた式（1）のような曲面を仮定する．なお， $\mathrm{x} ， \mathrm{y}$

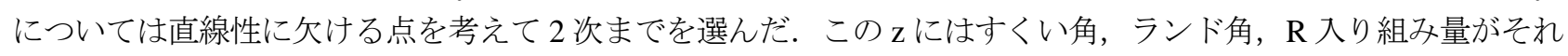
ぞれ対応する.この 3 つの変数（x，y，z）が式（2）を最小にするように最小二乗法を利用した曲面補間（山城 他，2003）を行い，a〜eのパラメータを算出する.

$$
\begin{aligned}
& z=a x+b y+c x^{2}+d y^{2}+e \\
& S=\sum_{i=1}^{n}\left(z_{i}-a x_{i}-b y_{i}-c x_{i}^{2}-d y_{i}^{2}-e\right)^{2}
\end{aligned}
$$

これにより最適な砥石設定(砥石振り角、砥石オフセット)のおおまかな值を算出することができる.さらに最 適な砥石設定を得るために，例えば砥石振り角 $\mathrm{x}$ の最大值と最小值間において細分化を行い， $\mathrm{z}$ を目標諸元值と して与え，式(1)に代入することで細分化された砥石振り角における砥石才フセットの值を計算する．以上のよ うな計算を行うと, 砥石振り角と砥石オフセットを変数としたすくい角・ランド角・R入り組み量(ストレート タイプの場合)の関係が求められる.フックタイプのドリルの場合、寸くい角とランド角を満たす適切な砥石振 り角と砥石オフセットが求まる. ストレートタイプでは, 寸くい角とランド角を満たす適切な砥石振り角と砥石 オフセットに加えて, 寸くい角と R入り組み量から砥石振り角と砥石才フセットが求まる. また, ランド角と $\mathrm{R}$ 入り組み量についても同様で，ここに 3 点が解の候補となる。そこで，この 3 つの解からなる領域を分割し， すくい角・ランド角・R入り組み量のドリル諸元の目標值との誤差が最小のものを最適な砥石設定とした.

\section{$3 \cdot 2$ 砥石設定のケーススタディ}

3.1 節で述べた手法を利用してあるストレートタイプのドリル製作のための砥石設定の予測を試みる. 初期值 は, 砥石振り角を $32^{\circ}$, 砥石オフセットを $0.1 \mathrm{~mm}$ とした. 振り角の探索範囲は初期值からプラス方向に $6^{\circ}$ ， マ イナス方向に $2^{\circ}$ まで, オフセットを $0.5 \mathrm{~mm}$ 以内と設定し, 探索の刻みを 30 とした. 図 13 は探索範囲内の砥石 設定でドリル諸元值が公差に収まる条件をそれぞれの諸元において曲面補間したもので，ドリル諸元の目標値を 平面で示している. そして, 3.1 節で述べた手法によって各ドリル諸元の目標值を満たす砥石設定を算出する. 対 象形状がストレートタイプであるので目標ドリル諸元值が 3 つであるため, 最適な砥石設定の解の候補が 3 つと なる. この 3 点に囲われた領域内をメッシュ分割し, ドリル諸元の目標諸元值との差が最も小さい值を算出し, 表 2 に示す計算結果を得た. 

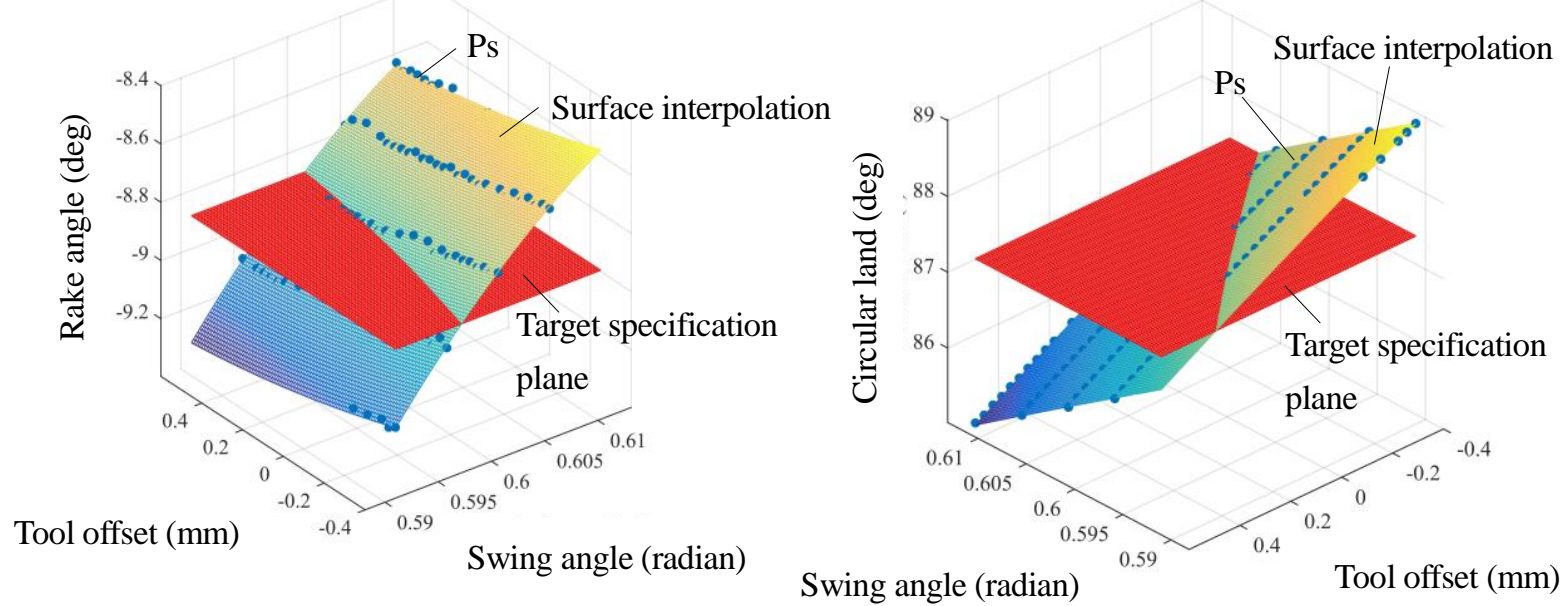

(a) Surface interpolation of rake angle data

(b) Surface interpolation of circular land data

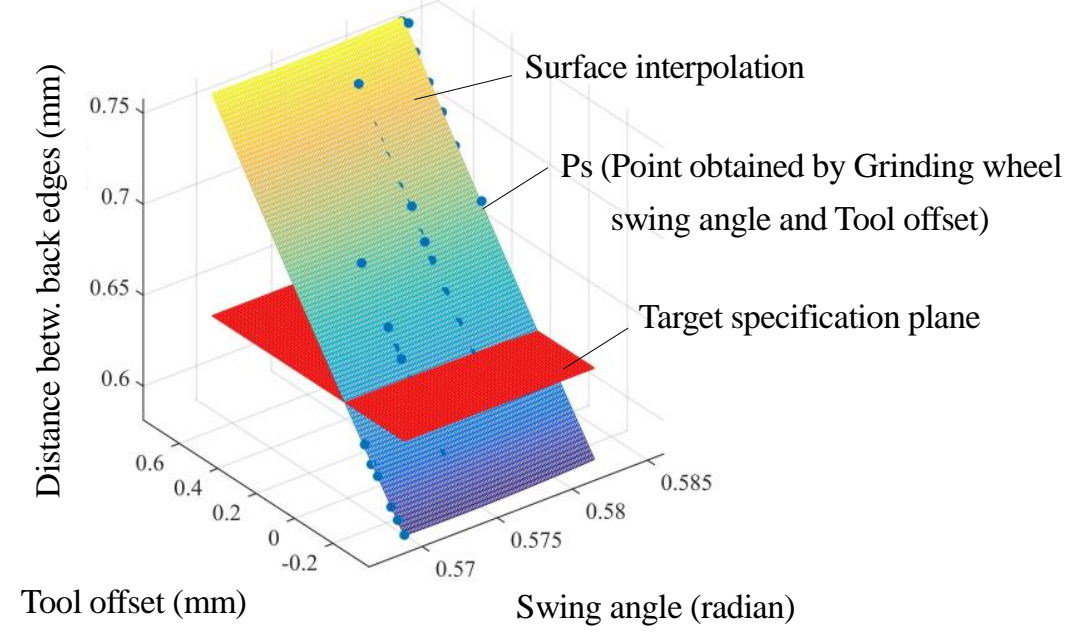

(c) Surface interpolation of distance between back edges data

Fig.13 Calculation result of surface interpolation

Table 2 Calculation result of the grinding wheel setting

\begin{tabular}{|c|c|c|}
\hline Grinding wheel setting & Target value & Calculated value \\
\hline Swing angle (deg) & 34.340 & 34.3432 \\
\hline Tool offset $(\mathrm{mm})$ & 0.000 & -0.0059 \\
\hline
\end{tabular}

以上の結果から，提案手法を用いることで初期值から目標砥石設定值とほぼ同じ值を算出することができ， 逆方向プロセスの有効性を確認した. 


\section{3-3 逆方向プロセスから順方向プロセスへの適応}

3.2 節で開発した逆方向プロセスでは，ドリル諸元と砥石形状を入力すると，通常は試行錯誤的に決めている 砥石設定情報を得られる．ここで得られた砥石設定情報を順方向プロセスに入力するとドリル形状と諸元が得ら れ，両プロセスが連結する。これを確認するために，表 2 で得られている砥石設定条件を使って，既存の外国製 ソフトウェアでドリル諸元を求めたものを参考值とし，本研究で開発した順方向システムで得られたドリル諸元 計算結果と比較したものが表 3 である.

Table 3 Comparison of the specification value under the condition of Table 2

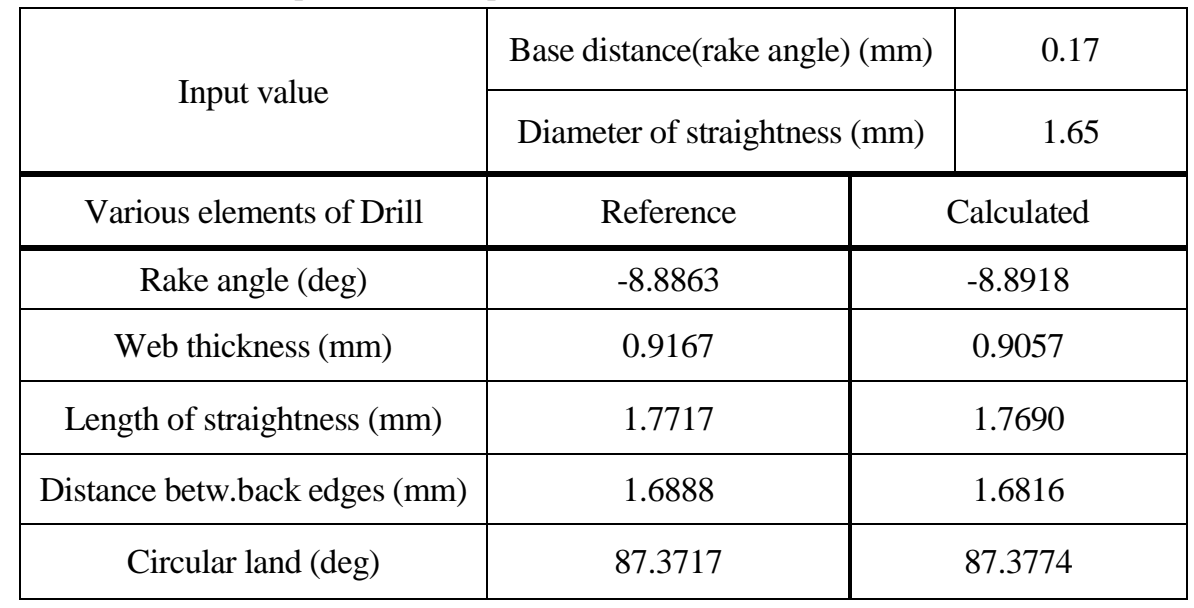

表 3 の結果より，参考值と順方向プロセスで得られた諸元の計算值とほぼ一致しており，開発したシステムの 有効性が確認できる.

\section{4. 結言}

本研究では，シミュレーションソフトウェア（オーエスジー社製）を使用して得られる研削砥石の軌跡からド リル断面形状の予測とドリル諸元の算出を可能にする手法を提案するとともに，砥石形状とドリル諸元から砥石 設定を予測する逆方向プロセスを扱えるシステム開発を行い，以下の結論を得た.

（1）各研削工程の研削軌跡データから凸包と MATLAB 関数 boundary を適用してシステムの基本となるドリル 溝外形点を抽出することができた.

（2）順方向プロセスとして，抽出したドリル外形点に基づいてドリル諸元を算出でき，これは参考值とほぼ同 じ值となった。このシステム開発で，シミュレーションソフトウェアは外国製ソフトウェアと同等なもの が構築できた。

（3）目標とするドリル形状諸元と砥石形状を与えると適切な砥石設定条件を得ることができるという逆方向の プロセスを完成できた。 このようなシステムは今までになく，ドリル作製に大きく寄与すると思われる.

（4）逆方向プロセスで算出した砥石設定条件と砥石形状とを順方向プロセスに入力することによって得られた ドリル諸元は参考值とほぼ一致し，順方向と逆方向の両プロセスの有効性を確認できた。 これにより，シ ミュレーションソフトウェアは完璧なものになりドリル製作の効率化が期待できる.

\section{文献}

濱田大地，中本圭一，石田 徹，竹内芳美，入れ子を有する複雑形状の巧妙加工，日本機械学会論文集C編, Vol.77, No.780 (2011), pp.3127-3136.

小畑智靖, 森重功一, 竹内芳美, 2次元C-Spaceを利用した5軸制御加工のための工具経路生成法一複雑形状加工に適 用するための処理の高速化と堅固化を重視した改良一, 精密工学会誌, Vol.70, No.2 (2004), pp287-291. 
小谷昂，中本圭一，石田徹，竹内芳美，複合加工機用CAMシステムの研究，日本機械学会論文集C編, Vol.75, No.757 (2009), pp.2589-2594.

窪田耕児，中本圭一，石田徹，竹内芳美，5軸加工を考慮した複合加工機用CAMシステムの開発，日本機械学会論 文集C編, Vol.76, No.770 (2010), pp.2729-2735.

松村隆, 切削シミュレーションの現状と課題, 精密工学会誌, Vol.80, No.9 (2014), pp.803-806.

大橋一仁, 前野隼人, 藤原良平, 窪田真一郎, 吉川満雄, 塚本真也, CFRP の研削特性に及ぼす加工雰囲気の影響 (水溶性クーラントおよび液体窒素供給の効果), 日本機械学会論文集 C 編, Vol.79, No.808(2013), pp.5068-5077.

岡田将人, 細川晃, 浅川直紀, 藤田祐介, 上田隆司, 低熱伝導率難削材のエンドミル加工における MQL の工具温 度一の影響, 日本機械学会論文集 C 編, Vol.78, No.792 (2012), pp.3093-3103.

曲棟梁, 西川清史, NL-means 雑音除去フレームワークのためのロバスト統計と方向性分散に基づく雑音判定精度 の改善法, 映像情報メディア学会技術報告, Vol.37, No.56 (2013), pp.37-40.

柴田順二, 古木拓夫, 豊田元弘, 綿貫芳雄, 清水哲, 三次元 NC 工具研削により創成されるフルート断面形状の解 析，日本機械学会論文集 C 編, Vol.58, No.554(1992), pp.234-239.

Yuqing S., Boundary fitting for 2D curve reconstruction, Springer, Vis Comput (2010), 26, pp.187-204.

山城光雄, 市川雄司, 久芳頼正, 指数関数を用いた 3 次元点群データの曲面補間，日本機械学会東北支部第 38 期 総会講演会講演論文集(2003), pp.74-75.

\section{References}

Hamada, D., Nakamoto, K., Ishida, T. and Takeuchi, Y., Dexterous machining for a complicated shape with nested structure, Transactions of the Japan Society of Mechanical Engineers, Series C, Vol.77, No.780 (2011), pp.3127-3136.

Kobata, T., Morishige, K. and Takeuchi, Y., Tool path generation for 5-axis control machining by means of 2-dimensional configuration space - speed up of processing time and increase of processing stability for machining of complicated shape-, Journal of the Japan Society for Precision Engineering, Vol.70, No.2 (2004), pp.287-291.

Kotani, T., Nakamoto, K., Ishida, T. and Takeuchi, Y., Development of CAM system for multi-tasking machine tools, Transactions of the Japan Society of Mechanical Engineers, Series C, Vol.75, No.757 (2009), pp.2589-2594.

Kubota, K., Nakamoto, K., Ishida, T. and Takeuchi, Y., Development of CAM system considering 5-axis machining for multitasking machine tools, Transactions of the Japan Society of Mechanical Engineers, Series C, Vol.76, No.770 (2010), pp.2729-2735.

Matsumura, T., Trends and issues in cutting simulation technologies, Journal of the Japan Society for Precision Engineering, Vol.80, No.9 (2014), pp.803-806.

Ohashi, K., Maeno, H., Fujihara, R., Kubota, S., Yoshikawa, M. and Tsukamoto, S., Influence of grinding atmosphere on grinding characteristics of CFRP (effect of soluble coolant or liquid nitrogen supply), Transactions of the Japan Society of Mechanical Engineers, Series C, Vol.79, No.808 (2013), pp.5068-5077.

Okada, M., Hosokawa, A., Asakawa, N., Fujita, Y. and Ueda, T., Influence of minimum quantity lubrication on tool temperature in end milling of difficult-to-cut materials having low thermal conductivity, Transactions of the Japan Society of Mechanical Engineers, Series C, Vol.78, No.792 (2012), pp.3093-3103.

Qu, D. and Nisikawa, K., Improving measures for noise decision accuracy based on the robust statistics and directivity distribution for a denoising framework, ITE Technical Report, Vol.37, No.56 (2013), pp.37-40.

Shibata, J., Huruki, T., Takada, Y., Toyoda, M., Watanuki, Y. and Shimizu, T., Simulation analysis of flute configuration generated in NC tool grinding, Transactions of the Japan Society of Mechanical Engineers, Series C, Vol.58, No.554 (1992), pp.234-239.

Yuqing, S., Boundary fitting for 2D curvere construction, Springer, Vis Comput (2010), 26, pp.187-204.

Yamashiro, M., Ichikawa, Y. and Kuba, Y., Surface interpolation of three dimensional data by the exponentia1 yype of curve, Proc. of $38^{\text {th }}$ General Meeting JSME Tohoku Branch (2003), pp.74-75. 